\title{
Simulasi Lemari Pengering Tenga Surya Dengan Prisma Kaca Menggunakan Computational Fluid Dynamics
}

\author{
(1)* Lohdy Diana, ${ }^{(2)}$ Arrad Ghani Safitra, ${ }^{(3)}$ Fifi Hesty Sholihah, ${ }^{(4)}$ Ahmad Taufiqurrahman Azhar \\ ${ }^{(1)(2)(3(4))}$ Program Studi Sistem Pembangkit Energi, Politeknik Elektronika Negeri Surabaya, Jl. Raya ITS Sukolilo \\ 60111, Surabaya \\ *Email:lohdydiana@pens.ac.id \\ Diterima: 25-04-2021, Disetujui: 29-05-2021, Diterbitkan: 30-05-2021
}

\begin{abstract}
The drying cabinet is an important part of a solar air heater. The drying cabinet was expected able to save the heat for a long time. That causes the thermal analysis on the dry cabinet need to do. The purposes of this study were to discover thermal and flow characteristics in the drying cabinet. The characteristics such as temperature distribution, temperature and velocity alteration, and airflow pattern. The method of this study was finite volume method form simulation using Computational Fluid Dynamic (CFD) simulation used 3D model in transient condition with time step 0.001. The data were taken at 5 seconds, 15 seconds, 25 seconds, and 35 seconds. The temperature distribution towards in time that happened at XY plane and XZ plane dry cabinet was obtained from the result simulation. Considering the result of simulation known to occur that decrease in temperature. The highest temperature was occurred in the under section from the drying cabinet with $333 \mathrm{~K}$. The prism on the top of the drying cabinet was able to store the heat in the air. The backflows have happened in the drying cabinet that caused the air heat from the inlet could not distribute uniformly.
\end{abstract}

\section{Keywords: drying cabinet, heat, simulation, temperature}

\begin{abstract}
ABSTRAK
Lemari pengering merupakan bagian penting pada pemanas udara tenaga surya. Lemari pengering diharapkan mampu menyimpan panas dalam waktu yang lama. Hal tersebut menyebabkan analisa thermal pada lemari pengering perlu dilakukan. Tujuan dari penelitian ini adalah untuk mengetahui karakteristik termal dan aliran yang terjadi pada lemari pengering. Karakteristik tersebut antara lain distribusi temperatur, perubahan temperatur dan kecepatan, dan pola aliran udara. Metode yang digunakan pada penelitian ini adalah Finite Volume Method berupa simulasi menggunakan software komputasi fluida atau Computational Fluid Dynamics, simulasi menggunakan model tiga dimensi pada kondisi transient dengan time step 0.015. Data simulasi diambil saat 5 detik, 15 detik, 25 detik, dan 35 detik. Hasil simulasi diperoleh perubahan distribusi temperatur udara terhadap waktu yang terjadi pada bidang XY dan bidang XZ lemari pengering. Berdasarkan hasil simulasi diketahui terjadi penurunan temperatur udara. Temperatur udara tertinggi terjadi pada bagian bawah lemari pengering dengan temperatur udara sebesar $333 \mathrm{~K}$. Prisma kaca pada bagian atas lemari pengering mampu memberikan panas pada udara. Terjadi aliran balik di dalam lemari pengering yang menyebabkan udara panas dari saluran masukkan tidak terdistribusi merata.
\end{abstract}

Kata Kunci: lemari pengering, panas, simulasi, temperatur

\section{Pendahuluan}

Indonesia memiliki musim yang sangat berbeda dengan negara lain. Musim di Indonesia yaitu musim hujan dan musim panas. Musim panas terjadi selama kurang lebih lima sampai dengan enam bulan. Sangat disayangkan energi matahari pada saat bulan- bulan tersebut apabila tidak dimanfaatkan. Pemanfaatan energi matahari secara tepat dapat memberikan secara tepat dapat memberikan keuntungan bagi masyarakat Indonesia. Keuntungan tersebut antara lain jumlah energi yang terus ada dan tidak mengotori lingkungan sekitar. Energi matahari dimanfaatkan untuk berbagai keperluan antara 
lain untuk penyinaran kehidupan sehari-hari, penyinaran photovoltaic sehingga dapat menghasilkan listrik, untuk pemanasan udara, pemanasan air, serta proses pengeringan. Proses pengeringan adalah serangkaian kegiatan untuk mengurangi kadar air di dalam produk yang dikeringkan. Kegiatan ini masih banyak dilakukan oleh masyarakat Indonesia. Hal tersebut dikarenakan Indonesia masih memiliki lahan pertanian yang sangat luas, dan kekayaan laut yang melimpah. Sehingga masyarakat yang mayoritas sebagai petani dan nelayan memerlukan alternatif proses pengeringan yang murah dan efektif. Solusinya adalah memanfaatkan energi matahari sebagai sumber pemanas atau dikenal dengan istilah pemanas udara tenaga matahari.

Alat pemanas udara tenaga matahari terus mengalami perkembangan hal tersebut dibuktikan dengan sejumlah penelitian yang telah dilakukan. Penelitian tersebut antara lain: penambahan fin pada permukaan kolektor yaitu berupa kawat aluminium berongga Porous Cylindrical Wire Mesh Fins yang diketahui pada kolektor gelombang (Rahul Khatri, 2020). Penambahan fin terbukti mampu meningkatkan perpindahan panas sehingga dapat meningkatkan efisiensi thermal pamanas udara surya (Hamdy, 2021) dan (H.S. Arunkumar, 2020) Penambahan kaca untuk merefleksikan panas matahari agar tertangkap oleh kolektor pada pemanas udara tenaga surya (Ashwini, 2020). Hal tersebut dilakukan untuk meningkatkan efisiensi thermal pemanas udara tenaga surya. Namun, pemanas udara tenaga surya memiliki salah satu komponen penting yaitu lemari penyaring. Hal tersebut dikarenakan lemari pengering yang baik adalah yang mampu menahan panas dalam waktu yang cukup lama. Meskipun kondisi sudah terbenam diharapkan proses pemanasan atau pengering masih dapat berlangsung. Beberapa inovasi lemari pengering tenaga surya telah dilakukan antara lain: penggabungan dua metode yaitu pengeringan langsung dan tidak langsung. Penggunaan kedua metode tersebut pada lemari pengering menghasilkan rasio moisture paling rendah jika dibandingkan dengan metode pengering langsung atau tidak langsung (Archana, 2018). Compact solar drying cabinet yaitu lemari pengering dengan turbin ventilator. Kecepatan rendah yang dihasilkan oleh turbin ventilator mampu menghasilkan udara panas sebesar $47^{\circ} \mathrm{C}-50$ ${ }^{\circ} \mathrm{C}$ (Woranuch, 2017). Penelitian secara simulasi dilakukan untuk melengkapi hasil pengujian eksperimen (Sundararajan ,2019) dan (Badrawada, 2019), Penelitian secara simulasi dilakukan untuk mendapatkan distribusi temperatur, distribusi tekanan, dan aliran fluida di dalam lemari pengering (Y. Amanlou, 2010) dan (Chapttip, 2019). Beberapa penelitian simulasi lemari pengering dilakukan untuk mengetahui distribusi temperatur dan distribusi tekanan terhadap perubahan waktu (Petros, 2019) dan (Abas Hadawey, 2018).

Penelitian ini menggunakan lemari pengering dengan prisma kaca pada bagian atas. Penelitian dilakukan secara simulasi menggunakan metode Computational Fluid Dynamics pada kondisi transient dengan time step $0,01 \mathrm{~s}$. Tujuan dari penelitian ini adalah untuk mengetahui distribusi temperatur, perubahan temperatur, kecepatan, dan pola aliran udara di dalam lemari pengering dan pada posisi centerline, serta manfaat prisma kaca pada lemari pengering. Hasil yang diperoleh dibandingkan untuk mengetahui performa lemari pengering dari waktu ke waktu. Dengan demikian akan menghasilkan desain lemari pengering yang dapat memanfaatkan tenaga matahai secara optimal.

\section{Metode Simulasi}

Penelitian ini dilakukan secara simulasi menggunakan metode komputasi fluida atau dikenal dengan istilah Computational Fluid Dynamics menggunakan finite volume method. Simulasi terdiri dari tiga tahapan antara lain: pre-processing, pro-processing, dan post processing. Tahapan pre-processing terdiri dari penggambaran object yang akan disimulasikan. Pada penelitian ini object tersebut adalah lemari pengering. Lemari pengering memiliki ukuran dengan koordinat X x Y x Z yaitu $0.4 \mathrm{~m}$ x $0.87 \mathrm{~m}$ x $0.5 \mathrm{~m}$. Lemari pengering memiliki tiga rak terdiri dari rak pertama yang merupakan alas lemari pengering atau berada pada posisi $Y=-0.77 \mathrm{~m}$ pada bagian bawah alas diberikan material insulasi sehingga kondisi batas sumulasi didefinisikan sebagai insulated wall, rak kedua berada pada posisi $\mathrm{Y}=-0.509 \mathrm{~m}$ terbuat dari aluminium, dan rak ketiga berada pada posisi $\mathrm{Y}=-0.255 \mathrm{~m}$ terbuat dari aluminium. Pada permukaan rak kedua dan ketiga terdapat enam lubang. Pada bagian atas lemari pengering terdapat prisma segiempat yang terbuat dari 
kaca dengan tebal $3 \mathrm{~mm}$. Dinding lemari pengering terbuat dari alumium dengan tebal 5 $\mathrm{mm}$. Saluran masukkan udara panas terletak di bagian bawah lemari pengering dengan ukuran diameter saluran $0.08 \mathrm{~m}$ terbuat dari aluminium. Lemari pengering dimodelkan dalam bentuk tiga dimensi. Bentuk lemari pengering ditunjukkan seperti pada Gambar 1 .

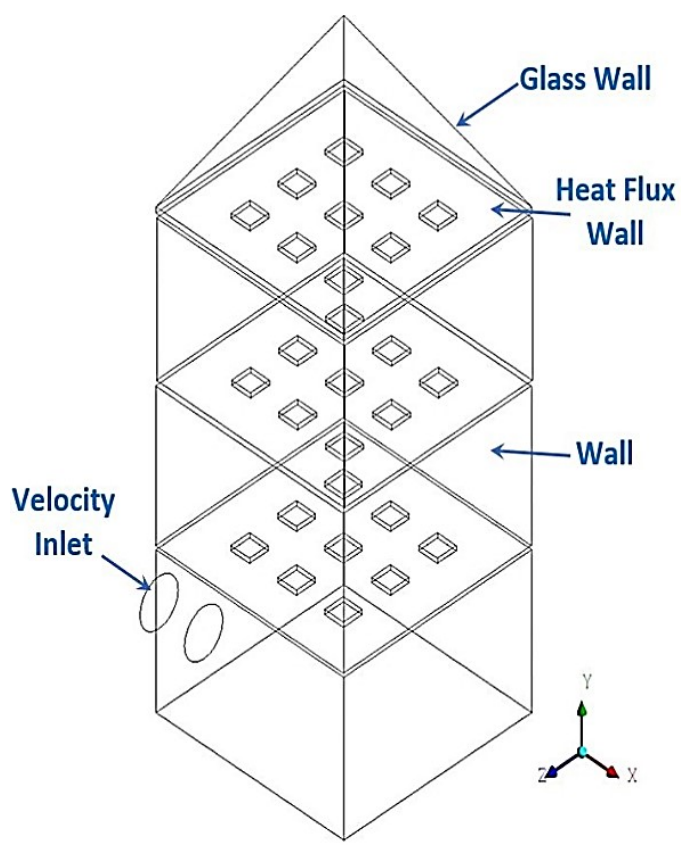

Gambar 1. Model Lemari Pengering

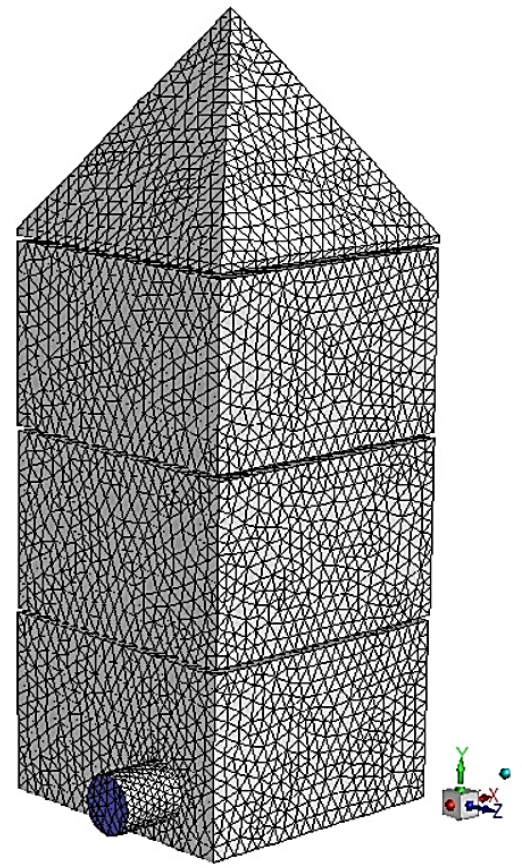

Gambar 2. Mesh Tetrahedral

Langkah kedua pada tahapan proprocessing yaitu melakukan meshing atau membagi object menjadi beberapa bagian kecil. Bentuk mesh yang digunakan pada simulasi ini adalah tetrahedral dengan elemen size $0.002 \mathrm{~m}$ seperti ditunjukkan pada Gambar 2. Meshing pada penelitian ini memiliki nilai skewness 0.23 dan nilai orthogonal 0.76 . Kedua hasil tersebut menandakan mesh memilki kualitas bagus dan dapat diterima. Tahapan selanjutnya adalah menentukan boundary condition atau kondisi batas. Kondisi batas untuk simulasi lemari pengering ditunjukkan pada Gambar 1. Tahap selanjutnya dikenal dengan istilah proprocessing yaitu tahapan parameter yang digunakan pada simulasi. Simulasi dilakukan pada kondisi transient atau perubahan waktu. Adapun propertis material dan fluida yang digunakan dapat dilihat pada Tabel 1 . Sedangkan parameter yang digunakan pada tahapan post-processing ditunjukkan pada Tabel 2.

Tabel 1. Properties Material dan Fluida

\begin{tabular}{clr}
\hline Material & \multicolumn{1}{c}{ Propertis } & \multicolumn{1}{c}{ Nilai } \\
\hline \multirow{3}{*}{ Aluminium } & Density & $2719 \mathrm{~kg} / \mathrm{m}^{3}$ \\
\cline { 2 - 3 } & Specific heat & $871 \mathrm{j} / \mathrm{kg} \cdot \mathrm{K}$ \\
\cline { 2 - 3 } Kaca & Thermal conductivity & $202.4 \mathrm{~W} / \mathrm{m} \cdot \mathrm{K}$ \\
\cline { 2 - 3 } & Density & $2500 \mathrm{~kg} / \mathrm{m}^{3}$ \\
\cline { 2 - 3 } & Specific heat & $870 \mathrm{j} / \mathrm{kg} \cdot \mathrm{K}$ \\
\cline { 2 - 3 } & Thermal conductivity & $1.022 \mathrm{~W} / \mathrm{m} \cdot \mathrm{K}$ \\
\hline \multirow{4}{*}{ Udara } & Density & $1.225 \mathrm{~kg} / \mathrm{m}^{3}$ \\
\cline { 2 - 3 } & Specific heat & $1006.43 \mathrm{j} / \mathrm{kg} \cdot \mathrm{K}$ \\
\cline { 2 - 3 } & Thermal conductivity & $0.0242 \mathrm{~W} / \mathrm{m} \cdot \mathrm{K}$ \\
\cline { 2 - 3 } & Viscosity & $1.789 \mathrm{x} 10^{-5}$ \\
& & $\mathrm{~kg} / \mathrm{m} . \mathrm{s}$ \\
\hline
\end{tabular}

Tabel 2. Parameter pada Post-processing

\begin{tabular}{lr}
\hline \multicolumn{1}{c}{ Parameter } & \multicolumn{2}{c}{ Keterangan } \\
\hline Solver type & Pressured-Based \\
\hline Viscous & Realizable k-epsilon \\
\hline Discritization & Second order upwind \\
\hline Continuity & $10^{-5}$ \\
\hline Energy & $10^{-6}$ \\
\hline Velocity inlet & $1 \mathrm{~m} / \mathrm{s}$ \\
\hline Velocity temperature & $330 \mathrm{~K}$ \\
\hline Wall heat flux & $950 \mathrm{w} / \mathrm{m}^{2}$ \\
\hline
\end{tabular}

Tahapan selanjutnya adalah validasi yaitu membandingkan nilai hasil simulasi dengan nilai teori. Nilai yang dibandingkan adalah parameter tanpa dimensi yaitu Bilangan Nusselt yang merupakan perbandingan koefisien konduksi dengan koefisien konveksi menggunakan persamaan Dittus-Boelter 
(Winterton, 1998).

$$
\mathrm{Nu}_{\mathrm{D}}=0.023 \operatorname{Re}_{\mathrm{D}}{ }^{4 / 5} \operatorname{Pr}^{2 / 5}
$$

\section{Hasil dan Pembahasan}

Berikut merupakan pembahasan hasil simulasi.

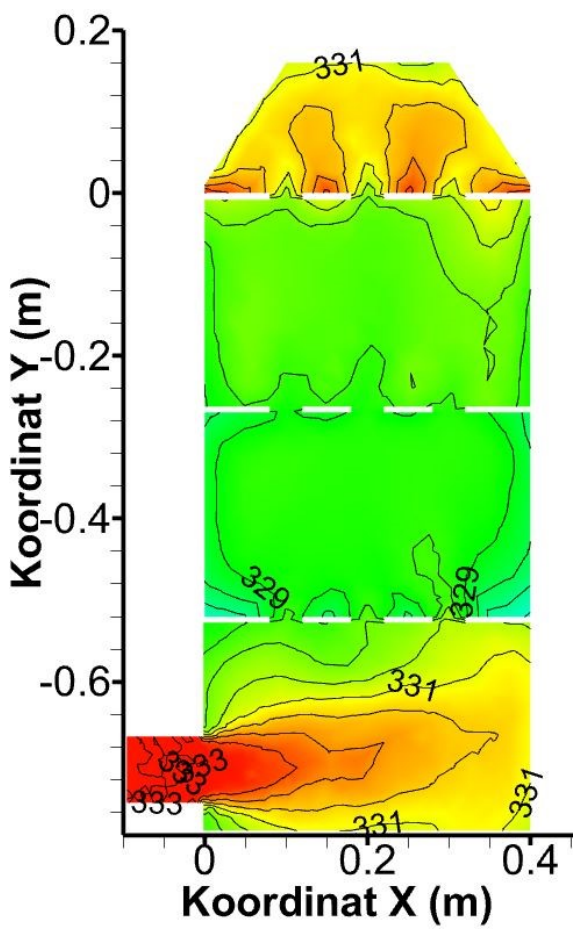

(a)

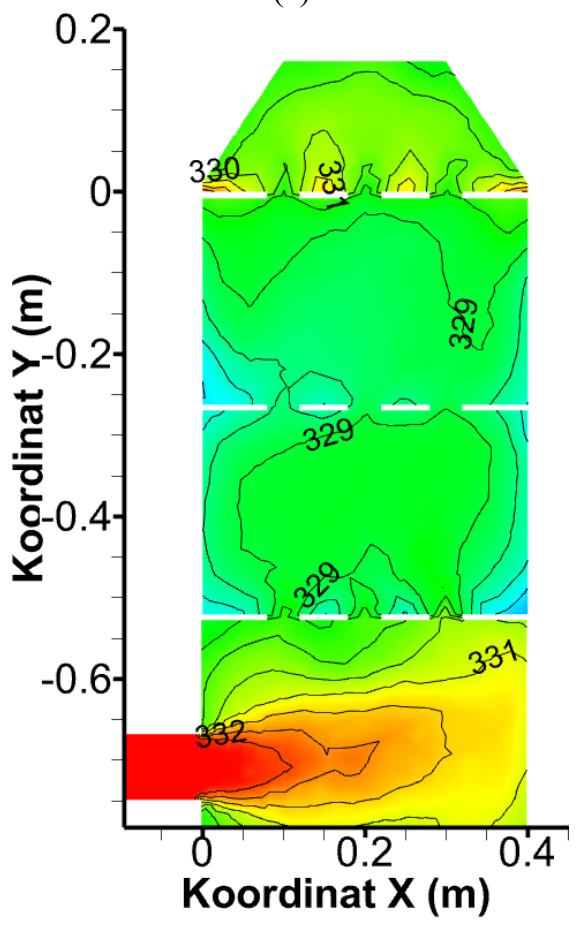

(b)

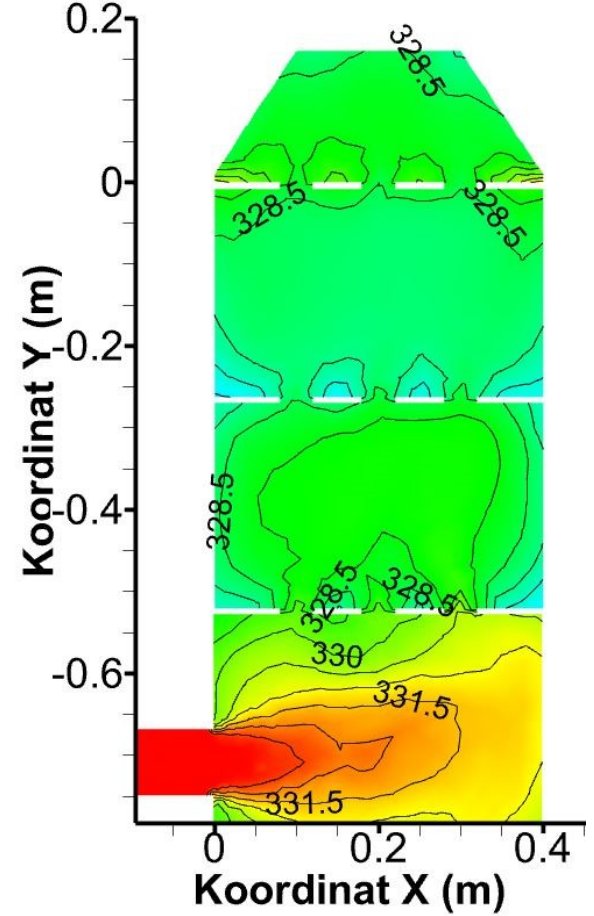

(c)

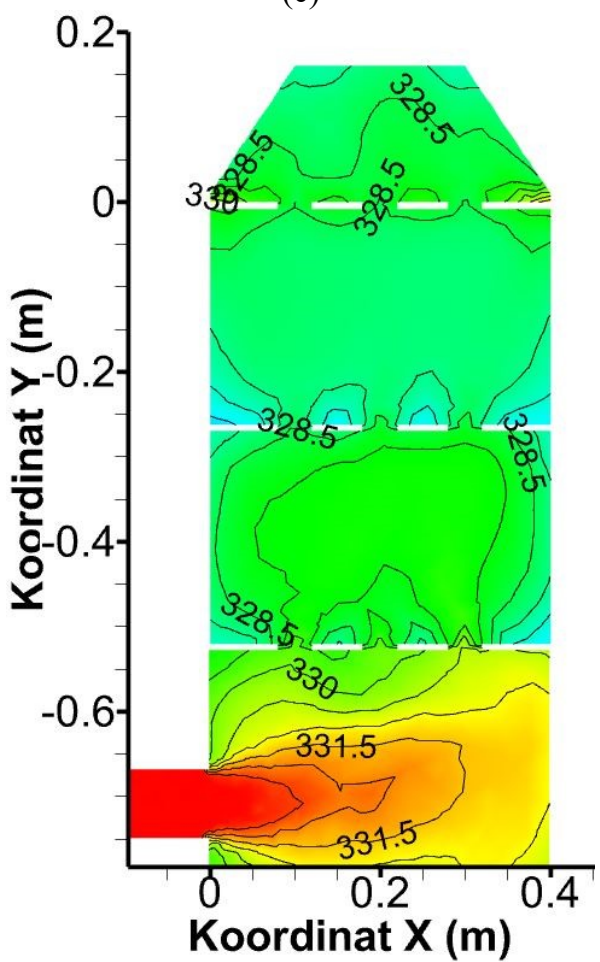

(d)

Gambar 3. Distribusi Temperatur Fluida (Udara) Pada Bidang XY saat (a) 5 detik, (b) 15 detik, (c) 25 detik, dan (d) 35 detik

Validasi simulasi merupakan tahapan dari post processing yang merupakan tahapan awal sebelum simulasi akan dianalisis. Pada tahapan validasi Bilangan Nusselt teori sebesar 27.4 dan Bilangan Nusselt simulasi sebesar 25.6. 
Berdasarkan nilai tersebut perbedaan nilai simulasi dan teori adalah sebesar $0.069 \%$. Gambar 3 menunjukkan distribusi temperatur udara pada bidang $\mathrm{XY}$ dengan koordinat $\mathrm{X}=$ $0.3 \mathrm{~m}$. Gambar 3(a) menunjukkan distribusi temperatur saat 5 detik. Berdasarkan Gambar 3(a) menunjukkan distribusi temperatur udara tertinggi terjadi di bagian bawah lemari pengering dan bagian atas lemari pengering. Hal tersebut terjadi dikarenakan bagian bawah lemari dekat dengan saluran masukkan udara panas. Sedangkan, bagian atas pengering alat yang terbuat dari aluminium yang menyerap panas matahari berupa heat flux sebesar 950 $\mathrm{W} / \mathrm{m}^{2}$ dengan temperatur udara tertinggi pada bagian tersebut sebesar $331 \mathrm{~K}$. Pada saat 15 detik temperatur udara di dalam lemari pengering mulai mengalami pencampuran terutama pada $\mathrm{Y}=-0.5$ dan $\mathrm{Y}=-0.3$ yaitu di atas rak kedua dan ketiga. Saat 25 detik terlihat temperatur udara mengalami penurunan pada bagian atas dan bagian bawah lemari pengering. Distribusi temperatur udara serupa ditunjukkan saat 35 detik. Berdasarkan Gambar 3 terjadi penurunan temperatur udara terhadap perubahan waktu menandakan terjadinya proses pendinginan di dalam lemari pengering. Hal tersebut diakibatkan pengaruh temperatur permukaan dinding lemari pengering. Penambahan kaca pada bagian atas lemari pengering cukup mampu memberikan panas tambahan pada udara yang sudah mengalami penurunan temperatur pada bagian atas rak ketiga. Hal tersebut ditunjukkan oleh distribusi temperatur udara pada saat 15 detik seperti pada Gambar 3(b).

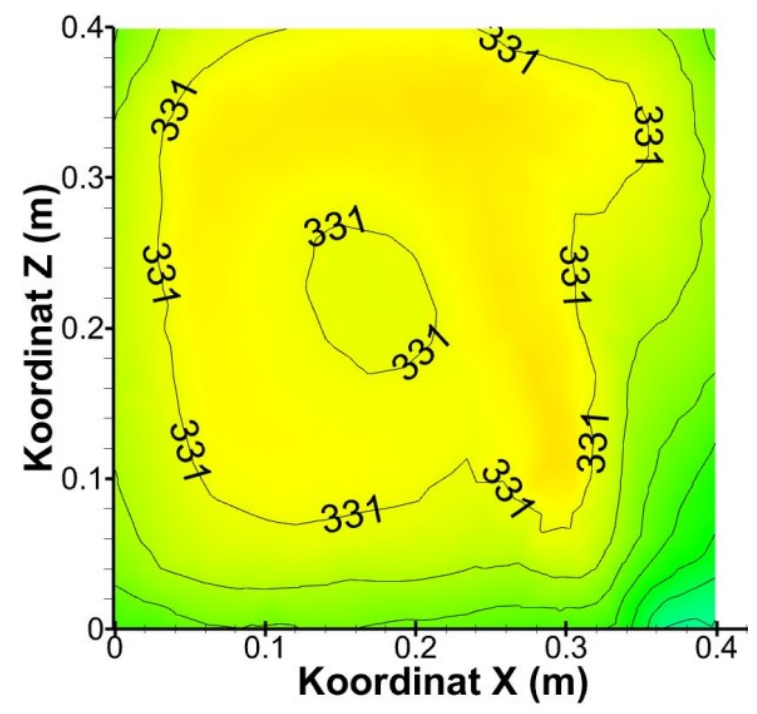

(a)

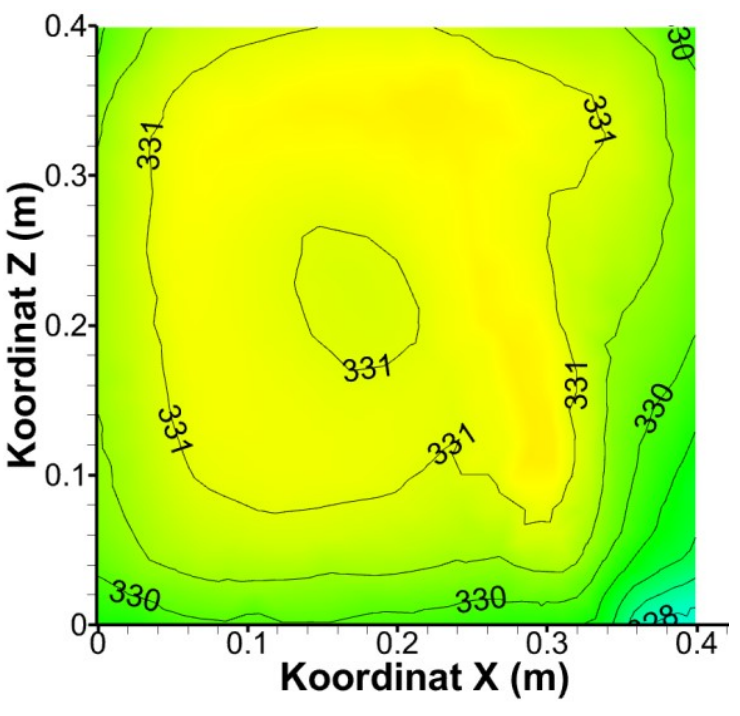

(b)

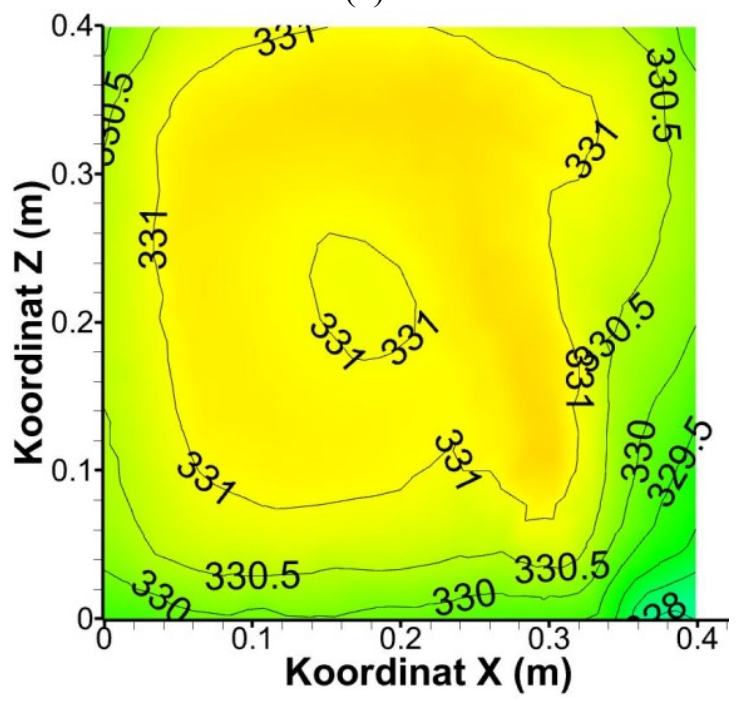

(c)

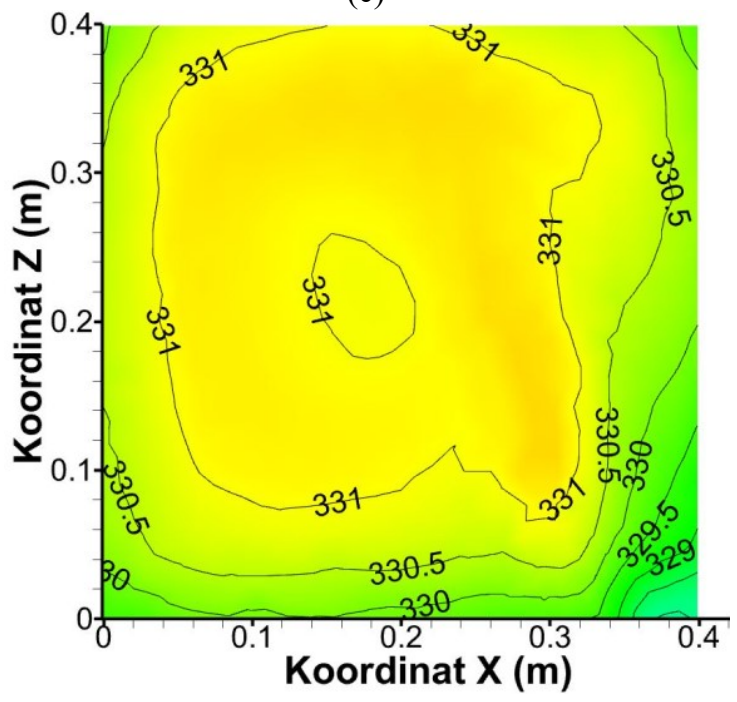

(d) 


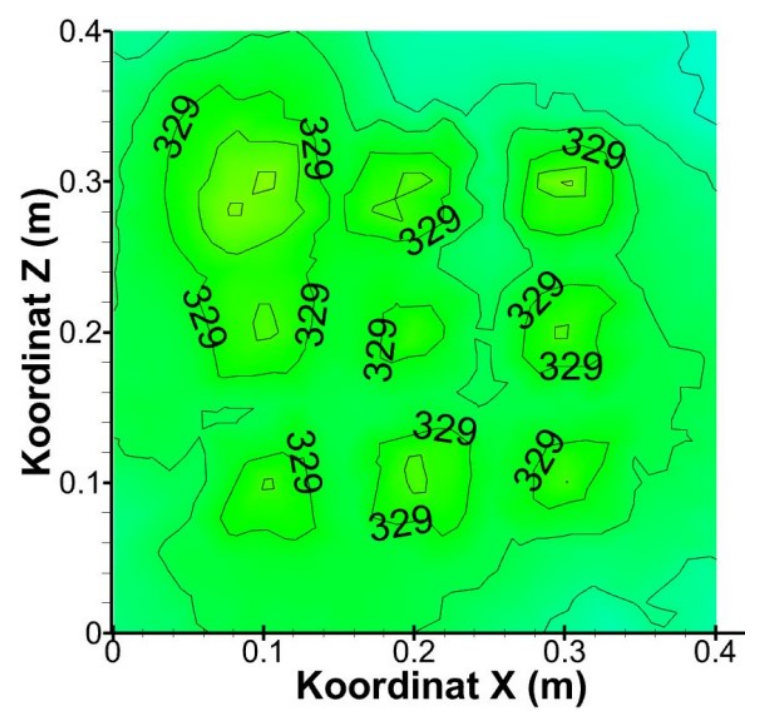

(e)

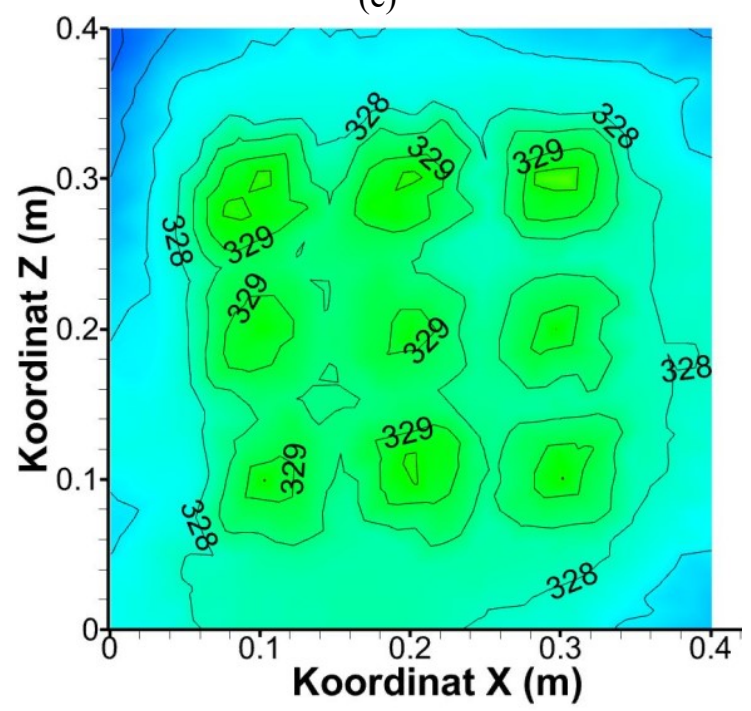

(f)

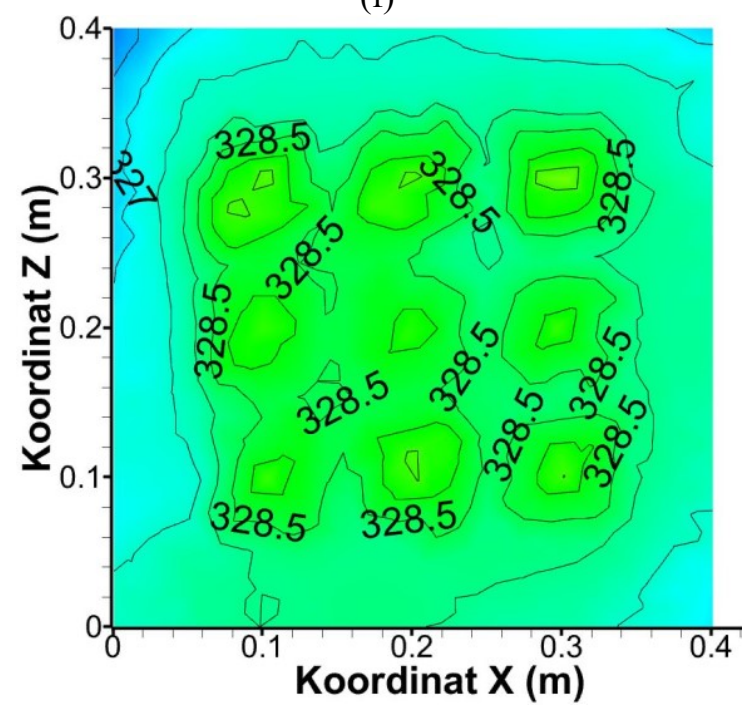

(g)

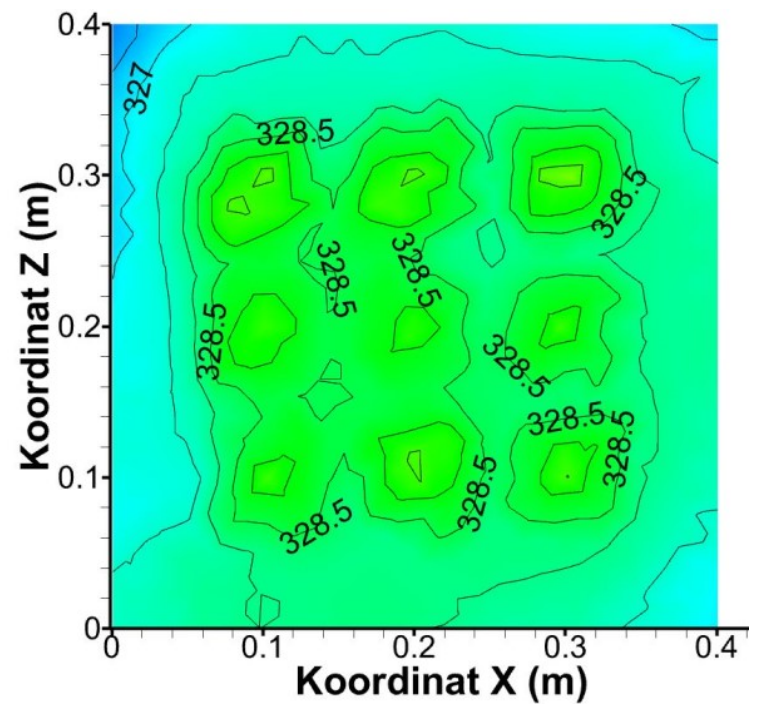

(h)

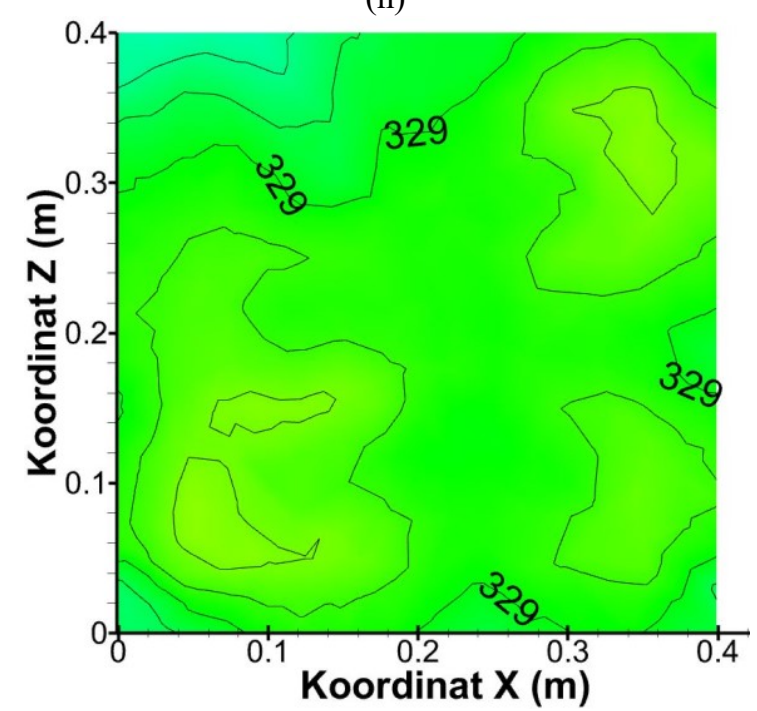

(i)

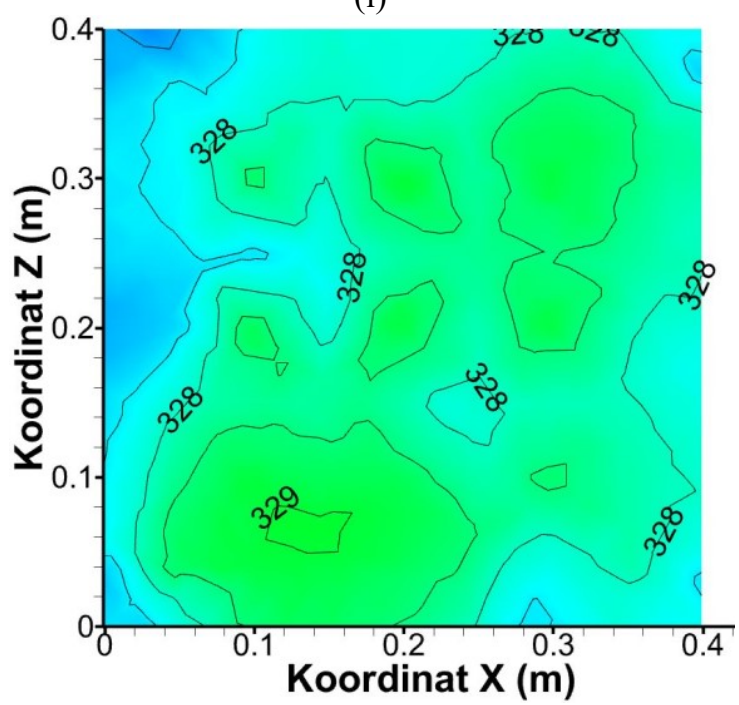

(j) 


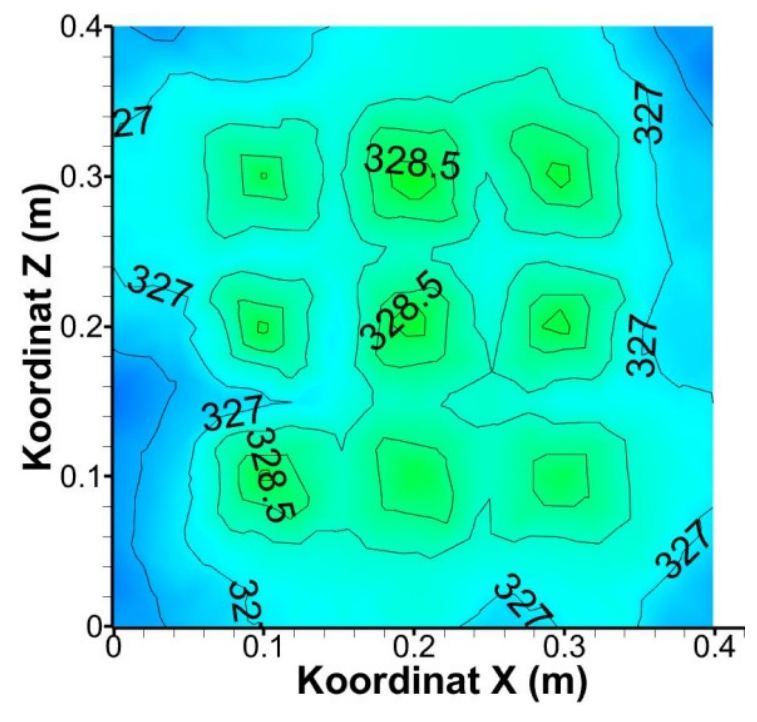

(k)

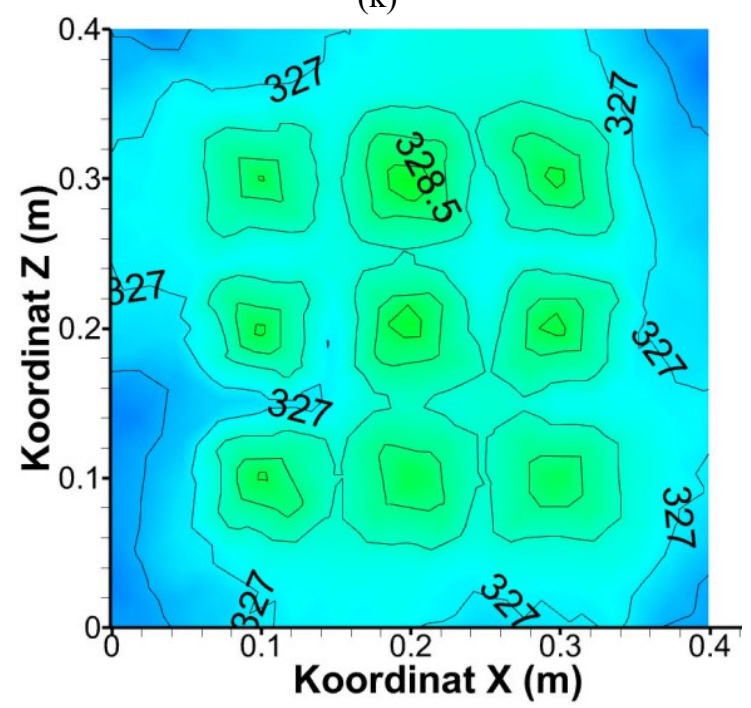

(1)

Gambar 4. Distribusi Temperatur Fluida (Udara) Pada Bidang XZ Rak Pertama (a) 5 detik, (b) 15 detik, (c) 25 detik, dan (d) 35 detik, Rak Kedua (e)

5 detik, (f) 15 detik, (g) 25 detik, dan (h) 35

detik,Rak Ketiga (i) 5 detik, (j) 15 detik, (k) 25

detik, dan (l) 35 detik,

Gambar 4 menunjukkan perubahan distribusi temperatur udara pada bagian atas, rak kedua, dan rak ketiga pada bidang XZ. Gambar 4(a), (b), (c), dan (d) menunjukkan distribusi temperatur udara pada bagian alas lemari rak pengering terhadap perubahan waktu saat 5 detik, 15 detik, 25 detik, dan 35 detik. Gambar tersebut menunjukkan tidak ada perubahan temperatur udara yang signifikan bahkan relatif sama semua waktu. Temperatur udara tertinggi terjadi pada bagian alas tengah alas sebesar 331K. Gambar 4(e), (f), (g), dan (h) menunjukkan distribusi temperatur udara pad arak kedua. Terjadi penurunan temperatur udara pada rak bagian kedua. Pada bagian ini aliran udara panas dari saluran masuk belum seutuhnya masuk karena tertahan oleh permukaan rak sehingga udara yang diteruskan hanya melewati enam lubang rak pada bagian tengah. Hal tersebut yang menyebabkan temperatur udara bagian tengah lebih tinggi dibandingkan bagian tepi rak. Penurunan temperatur juga ditunjukkan pada gambar 4(i), (j), (k), dan (1). Namun penurunan yang terjadi pad arak ketiga tidak terlalu signifikan. Hal tersebut dikarenakan mendapat panas pada alas prisma kaca yang menerima panas berupa heat flux.

Penurunan temperatur udara secara kuantitatif ditunjukkan pada Gambar 5(a) yang merupakan grafik temperatur udara di sepanjang garis tengah atau centerline pada lemari pengering. Berdasarkan Gambar 5 temperatur udara pada bagian bawah lemari pengering $\mathrm{Y}=-0.72$ sampai $-0.65 \mathrm{~m}$ memiliki nilai tertinggi sekitar $331 \mathrm{~K}$ dikarenakan pada bagian tersebut terdapat saluran masukan udara panas. Kemudian temperatur mengalami penurunan ketika $Y=-0.56$ sampai -0.33 . Hal tersebut dikarenakan udara panas tidak sepenuhnya masuk pada bagian tersebut. Ketiga $\mathrm{Y}=-0.24$ sampai $0.21 \mathrm{~m}$ temperatur udara mengalami peningkatan sekitar $4 \mathrm{~K}$. Hal tersebut terjadi karena ada tambahan panas berupa heat flux dari alas prisma kaca.

Gambar 5(b) menunjukkan kecepatan udara yang terjadi di dalam lemari pengering. Berdasarkan Gambar 5(b) kecepatan udara tertinggi terjadi di dekat saluran masukkan udara yaitu pada posisi $\mathrm{Y}=-0.53 \mathrm{~m}$ selanjutnya kecepatan udara mengalami penurunan. Hal tersebut menyebabkan udara panas yang masuk ke dalam lemari pengering belum sepenuhnya mengalir pada seluruh bagian lemari yang menyebabkan udara panas dari saluran masukkan tidak terdistribusi rata ke seluruh lemari. Kecepatan aliran udara yang terjadi pada lemari pengering seperti ditunjukkan pada Gambar 6. 


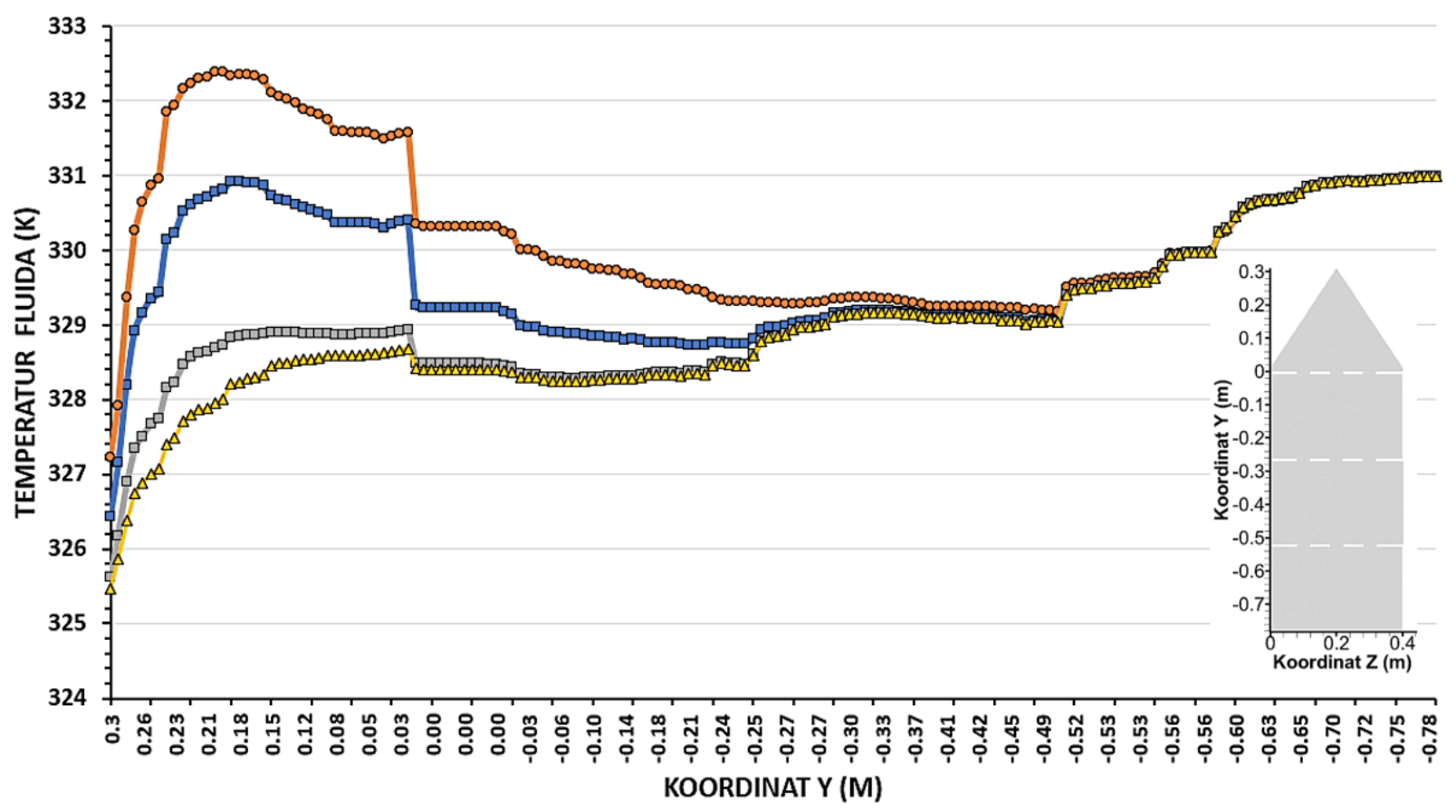

(a)

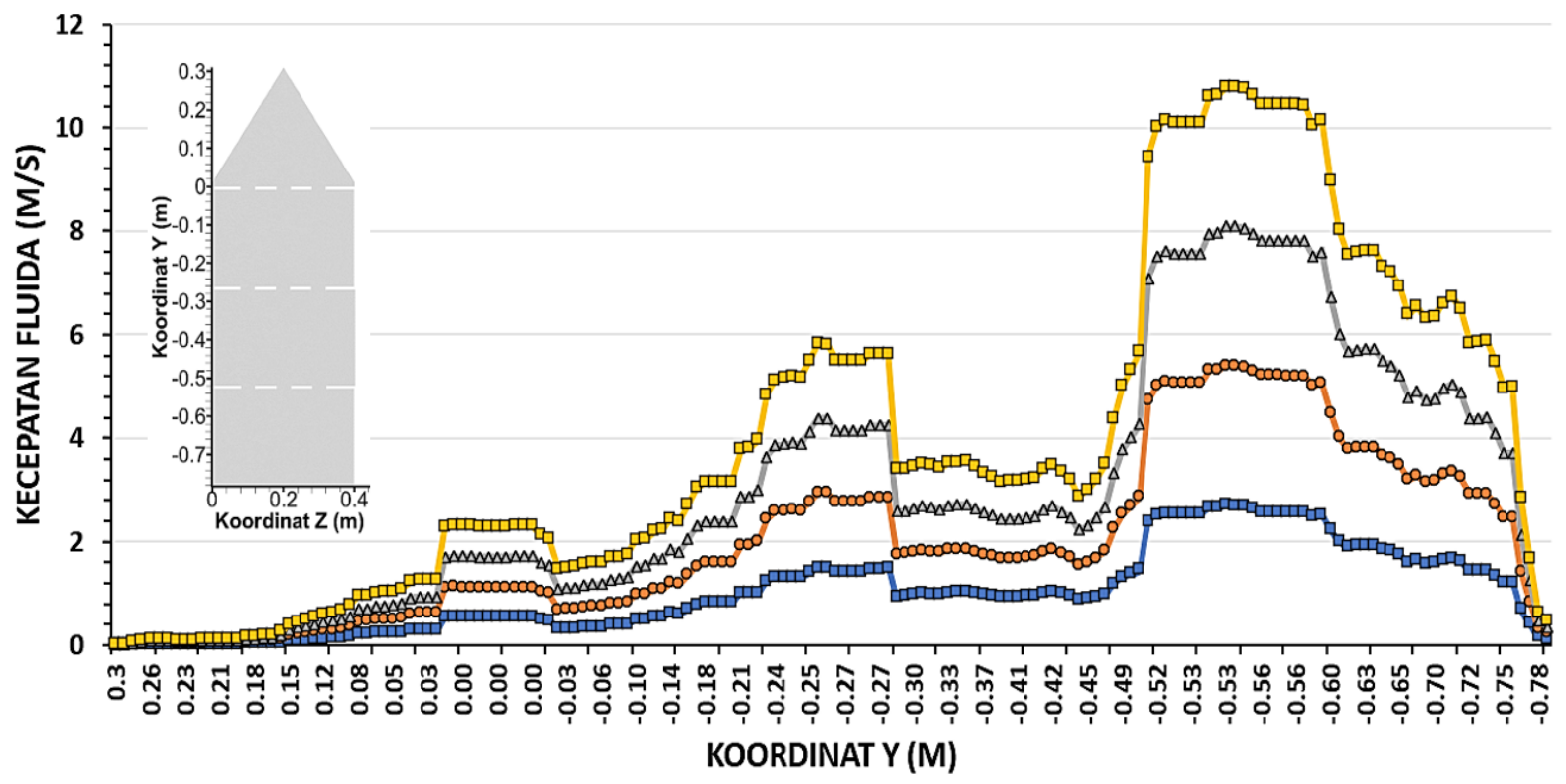

$=-\mathrm{t}=5$ detik $\quad-0=t=15$ detik $\quad-\Delta=t=25$ detik $\quad \square=t=35$ detik

(b)

Gambar 5. Grafik Sepanjang Centerline terhadap (a) Temperatur Fluida (Udara), (b) Kecepatan Fluida (Udara). 


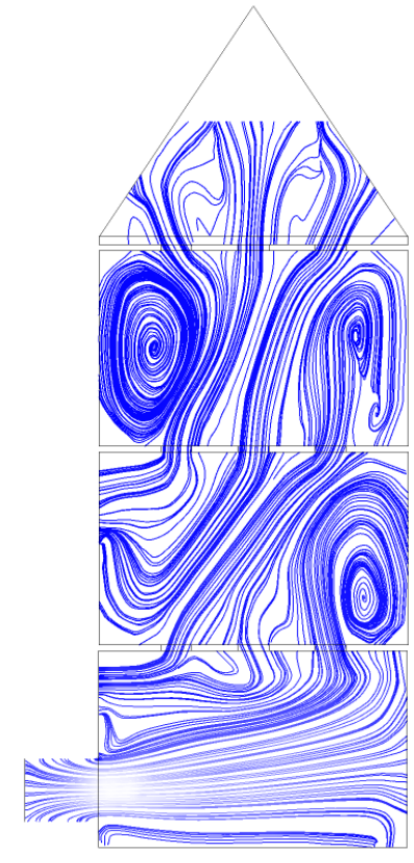

(a)

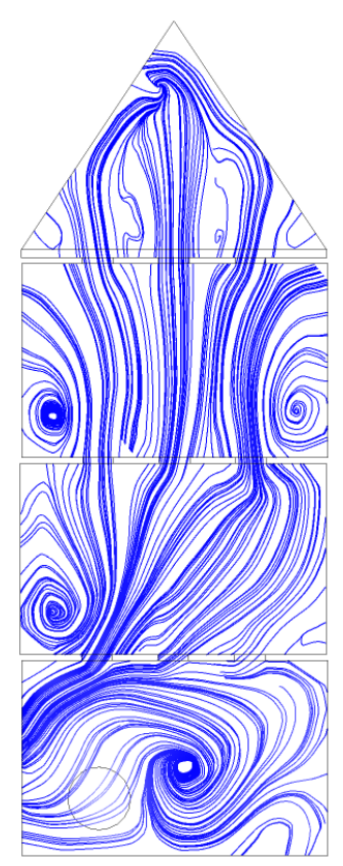

(b)

Gambar 6. Aliran Fluida pada Bidang (a) XY dan (b) $Z Y$

Berdasarkan Gambar 6 terlihat terdapat sejumlah aliran balik yang terjadi terutama di bagian ujung lemari pengering. Hal tersebut menyebabkan udara panas terjebak pada ruang yang sama sehingga panas tidak terdistribusi merata ke seluruh bagian lemari pengering. Berdasarkan hasil karakteristik termal dan aliran perlu penambahan saluran luaran yang diletakkan pada bagian atas dan bersebrangan dengan saluran masukkan, kemudian menambah jumlah lubang pada permukaan rak dengan demikian akan menghasilkan desain lemari pengering yang lebih baik.

\section{Kesimpulan}

1. Distribusi temperatur udara di dalam lemari pengering tidak seragam. Temperatur udara tertinggi terjadi pada bagian bawah dan bagian atas lemari pengering dengan temperatur udara tertinggi $333 \mathrm{~K}$.

2. Lemari pengering pada bidang $X Y$ dan $X Z$ mengalami perubahan atau mengalami penurunan temperatur udara terhadap perubahan waktu.

3. Kecepatan udara tertinggi terjadi di dekat saluran masukkan udara yaitu pada posisi $\mathrm{Y}=-0.53 \mathrm{~m}$ selanjutnya kecepatan udara mengalami penurunan.

4. Terjadi sejumlah aliran balik di bagian ujung lemari pengering menyebabkan udara panas terjebak sehingga panas tidak terdistribusi merata ke seluruh bagian lemari pengering.

5. Penambahan prisma kaca pada bagian atas lemari pengering mampu berkontribusi untuk memberikan panas pada udara yang mengalir ke atas lemari pengering.

\section{Ucapan Terima Kasih}

Penulis mengucapkan terima kasih kepada Politeknik Elektronika Negeri Surabaya yang telah mensponsori penelitian dan Program studi Sistem Pembangkit Energi yang telah bekerjasama dalam grup riset sehingga penelitian dapat berjalan lancar.

\section{Daftar Pustaka}

Archana dan Punyadarshini. (2018). Modeling and Simulation of Moisture Transfer during Solar Drying of Carrot Slice. Wily Journal of food Processing. India.

Ashwini, K., A, K, Behura., S, Saboor., \& Hemant, K, G. (2020) Comparative Study on W-Shaped Roughened Solar Air Heaters by Using Booster Mirror. Materials Today : Proceedings,.

Badrawada I Gusti Gde, Purwanto Adi, Edo Firlanda. (2019). Analisaaerodinamika Bodi Kendaraan Mataram Proto Diesel 
Dengan Ansys 15.0. Jurnal ENGINE: Energi, Manufaktur, dan Material, Vol. 3(1), hal: 8-14.

Chattip, P., N, Tharangkool., Prasert, P., P, Ponpesh., \& T, Jalunglumret. (2019) Computational Fluid Dynamic Design of Spent Coffee Ground Cabinet Dryer Using Recycled Heat From Air Compressor. Journal Pre Proof, S02638762(19)30487-3.

H, S, Arunkumar., Shiva, K., \& K, V, Karanth. (2020). Analysis of a Solar Air Heater Augmented Thermohydraulic Performance Using Helicoidal Spring Shaped Fins a Numerical Study. Renewable Energy.

Hamdy, H., M, S, Yousef., \& S, Abo-Elfafl. (2021). Energy, Exergy, Economic and Enviromental Assesment of Double Pass V-Corrugated Perforated Finned Solar Air Heater at Different Air Mass Ratios. Sustainable Energy Technologies Assessments 43, 10096.

Petros, D, T., Mekonnen, G, G., \& Maarte, V. (2019) On the Comparison between Computational Fluid Dynamics and Lumped Capacitance Modeling for The Simulation of Transient Heat Transfer in Solar Dryers. Solar Energy, 184, 417-425.

Rahul, K.,S, Goswani., M, Anas., S, Sharma., Satvik, A., \& Shivansh, A. (2020). Performance Evaluation of an Arched Plate Solar Air Heater with Porous Aluminium Wire Mesh Cylindrical Fins. $20207^{\text {th }}$ International Conference on Power and Energy Systems Engineering (CPESE 2020), 627633.

Sundararajan. (2019) Numerical Investigation into The Product's Weight Loss and Display Shelf Life Inside The Serve-Over Cabinet. ScienceDirect Energy Procedia, 161, 317-324.

Winterton, R. H. S., Int. J. Heat Mass Transfer, 41, 809, 1998.

Woranuch Jangsawang. (2017). Meat Product Drying with a Compact Solar Cabinet Dryer. International Conference on Alternative Energy in Developing Countries and Emerging Economies. Thailand.

Y, Amanlou \& A, Zomorodian. (2010) Applying CFD for Designing a New Fruit Cabinet Dryer. Journal of Food Engineering, 101, 8-15. 